\title{
Looking Ahead: Racial Trends in the United States
}

\section{Citation}

Hochschild, Jennifer L. 2005. Looking ahead: Racial trends in the United States. Daedalus 134, no. 1: 70-81.

\section{Published Version}

http://dx.doi.org/10.1162/0011526053124343

\section{Permanent link}

http://nrs.harvard.edu/urn-3:HUL.InstRepos:3200608

\section{Terms of Use}

This article was downloaded from Harvard University's DASH repository, and is made available under the terms and conditions applicable to Other Posted Material, as set forth at http:// nrs.harvard.edu/urn-3:HUL.InstRepos:dash.current.terms-of-use\#LAA

\section{Share Your Story}

The Harvard community has made this article openly available.

Please share how this access benefits you. Submit a story.

\section{Accessibility}




\title{
Jennifer L. Hochschild
}

\author{
Looking ahead: \\ racial trends in the United States
}

$\mathrm{I}_{\mathrm{n}}$ n April of 2004, the quarterly newsletter Migration News summarized the most recent data on race and ethnicity from the U.S. Census Bureau: "In 2000, the racial/ethnic makeup of US residents was: White, 69 percent; Hispanic and Black, 13 percent each; and Asian and other, six percent. By 2050, these percentages are projected to be: $50,24,15$, and 13." For anyone who has been studying racial trends in America these figures weren't surprising. ${ }^{1}$ But the newsletter's

Jennifer L. Hochschild is Henry LaBarre Jayne Professor in the department of government and professor in the department of African and African American Studies at Harvard University. A Fellow of the American Academy since 1996, she studies the intersection of American politics and political philosophy, and educational policy. Her books include "The American Dream and the Public Schools" (with Nathan Scovronick, 2003), "Facing Up to the American Dream: Race, Class, and the Soul of the Nation" (1995), "The New American Dilemma: Liberal Democracy and School Desegregation" (1984), and "What's Fair: American Beliefs About Distributive Justice" (1981). She is the founding editor of "Perspectives on Politics," a new journal published by the American Political Science Association.

(C) 2005 by the American Academy of Arts \& Sciences conclusion certainly was: "It is possible that, by 2050, today's racial and ethnic categories will no longer be in use."

Migration News is a scholarly publication that "summarizes the most important immigration and integration developments." 2 It is produced by Migration Dialogue, a group at the University of California, Davis, that aspires to provide "timely, factual and nonpartisan information and analysis of international migration issues." Migration News cannot by any stretch of the imagination be described as fanciful or ideological - and yet in the middle of a summary of census data its authors produced the astonishing prognosis that "by 2050, today's racial and ethnic categories will no longer be in use." If Migration News is correct, residents of the United States will, within the lifetime of many readers of this issue of Doedalus, no longer talk of blacks, whites, Asians, Latinos, and Native Americans, but will instead speak of - what?

1 This essay is part of a joint research project with Traci Burch and Vesla Weaver, both Ph.D. students at Harvard University. I thank them for their contributions to our shared enterprise. The views expressed in this essay are my own, and not necessarily shared by these coauthors of the larger project.

$2<$ http://migration.ucdavis.edu/>. 
This essay explores possible answers to that tantalizing question. By looking backward at racial and ethnic constructions and practices in the United States over the past century, we will be better situated to project possible racial and ethnic constructions and practices over the next one. Migration News might well be right - although, as I will argue, that is a far cry from predicting that the old shameful racial hierarchies will disappear.

The idea of ethnicity did not exist in
19oo; the term 'ethnic' was invented
around World War I and came into
widespread use in the 193os. The term
'race' did much of the work that we now
assign to 'ethnicity'; phrases such as 'the
Irish race,' 'the Yankee race,' and 'the
Hebrew race' were common and uncon-
tested. But race meant a lot more than
ethnicity. Edgar Allen Poe wrote of "the
race of Usher," Charles Dickens, of "the
race of Evrémonde.” Biologists mea-
sured cranial capacities and developed
intelligence testing in order to make
what they perceived to be scientific de-
terminations of the biological differ-
ences among races of humans. In 1939
Carleton Coon, a physical anthropolo-
gist at Harvard University, published
The Races of Europe, a textbook that
named eighteen races that were spread
across the continent, including “Partial-
ly Mongoloid,” "Brunn strain, Tronder
etc., unreduced, only partly brachyce-
phalized,” "Pleistocene Mediterranean
Survivor," "Neo-Danubian,” and so on.
Meanwhile, the Negro and Indian races
were routinely distinguished from the
white race.
A century later we retain the term
'race,' but only in the last of these us-
ages, that is, distinguishing a few major
groups from each other. A family is de-
scribed by ancestry, lineage, or descent -

not by race. The Irish are an ethnic group; to identify someone as a Yankee is to evoke a regional or cultural distinction; Jews are an amalgam of religion, ethnicity, and perhaps culture. Anthropologists no longer make racial distinctions among Europeans; in fact, current research in the field of cultural studies typically identifies all Europeans, from Swedes to Arabs, as a single race distinguished by its whiteness.

The biology of race has also changed dramatically. A century ago, biologists held that there were many races, that races could be distinguished from one another in objective and quantifiable ways, and that less measurable but nonetheless real differences in intelligence and emotional maturity were closely associated with measurable differences in skull size or proportion of white ancestry. Some still held that races had different origins or were even different subspecies. By the middle of the twentieth century, however, the number of commonly recognized races had shrunk to a few (in grade school, I learned about Caucasoids, Mongoloids, Negroids, and Indians). And by the end of the century, conventional wisdom, at least among scholars, held that a race was a purely social construction with no notable biological differences.

The wheel may be turning again, however. That well-known exemplar of postmodern deconstructionism, the U.S. census, is leading the way in proliferating racial identities: the census now recognizes 126 ethnoracial groups (or a mere 63 racial groups!) and, as Kenneth Prewitt points out, many more could come in quick succession. At the same time, some scientists and medical doctors are contesting the view that race is nothing but a social construction; as Neil Risch and his coauthors put it, "a 'race-neutral' or 'color-blind' approach 
Jennifer L. Hochschild on race to biomedical research is neither equitable nor advantageous, and would not lead to a reduction of disparities in disease risk or treatment efficacy between groups."3 People of different races or ethnicities may react differently to particular medications, may be especially susceptible to specific diseases, or may have bone marrow or kidneys compatible only with some co-ethnics. Most new biological research has been purified of the old eugenicist motivations; even the dean of Howard University Medical School has endorsed a major initiative to collect DNA samples from his hospital's (mostly black) patients for medical research on diseases to which African Americans are especially prone, such as high blood pressure, asthma, and prostate cancer. By 2050 the historical seesaw between biology and social constructivism may be superseded by genomic research that disaggregates individuals at levels far below any groupings by race, ethnicity, geography, or culture.

In parallel with the changing meanings of race, we have witnessed the rise and perhaps fall of the concept of ethnicity. That concept was invented partly in opposition to the idea of race, since it was taken to denote possibly malleable culture rather than biologically fixed characteristics. It was elaborated as a way to make distinctions within a given race, usually among whites; Michael Novak wrote in 1972 of "the rise of the unmeltable ethnics" within various European nationalities. Some analysts continue to insist that the two terms should be defined in opposition to each other. I, like other undergraduate lecturers, have taught my students that Latinos have a common ethnicity shared among multi-

3 Neil Risch, Esteban Burchard, Elad Ziv, and Hua Tang, "Categorization of Humans in Biomedical Research: Genes, Race, and Disease," Genome Biology 3 (7) (2002): 1- 12. ple races, whereas Pacific Rim Asians are a single race with multiple ethnicities.

But scholars and activists are now working to confound the distinction that was developed over most of the past century. Ian Haney López, for example, wrote in 1997 that "conceptualizing Latinos/as in racial terms is warranted .... The general abandonment of racial language and its replacement with substitute vocabularies, in particular that of ethnicity, will obfuscate key aspects of Latino/a lives." 4 Four in ten of those who identified as Hispanic or Latino on the ethnicity question in the 2000 census rejected all the racial categories offered to them in the next question, in favor of "some other race." Whether that represents a principled refusal to distinguish race from ethnicity, or just respondents' confusion with the census form, as the Census Bureau interpreted it, remains to be seen. David Hollinger has pointed out one of the more resonant ironies of American racial politics: the same federal government that separates Hispanic ethnicity from race in the census treats Hispanics as legally equivalent to African Americans in antidiscrimination policies such as affirmative action, voting rights, and minority set-asides.

Residents of the United States began the twentieth century by not distinguishing a race from an ethnicity; they spent most of that century elaborating the differences between the two concepts; and they appear now to be collapsing the distinction. The number of recognized races shrank drastically and is now expanding again. When the century began, the concept of race was tightly connected with the biological sciences; that bond was almost snapped but now may be regaining strength. I am

4 Ian Haney López, "Race, Ethnicity, Erasure: The Salience of Race to LatCrit Theory," California Law Review 85 (5) (1997): 1143-1211. 
not making a simple cyclical argument: the proliferation of races through multiple self-definitions is very different from the mapmaking of a physical anthropologist, and the biology of eugenics is unconnected with the biology of the genome project. Nevertheless, the transformations of the past century show that Migration News's casual suggestion that by 2050 today's racial and ethnic categories may no longer be in use is not as farfetched as it initially appears to be.

\section{$\mathrm{D}$} efinitions and usages of concepts such as race and ethnicity matter because they help us to understand the practice of racial and ethnic interaction. If immigrants are regarded as a race apart, biologically distinct from the rest of us, they will be treated very differently than if they are regarded as belonging to another ethnicity, similar in crucial ways to all the others. The structure of racial hierarchy will be different if races are conceived as discrete and insular (i.e., one can be black or white but not both) rather than if they are conceived as occurring along a continuum. The degree to which such conceptions and practices have changed over the past century can give us hints as to how they are likely to change over the next one.

Consider immigrants first. Ever alert to its responsibility as the newspaper of record, The New York Times reminded readers in the 188 os of "a powerful 'dangerous class,' who care nothing for our liberty or civilization, ... who burrow at the roots of society, and only come forth in the darkness and in times of disturbance, to plunder and prey on the good things which surround them, but which they never reach." This is, the Times proceeded to warn, "the poorest and lowest laboring class ... [who] drudge year after year in fruitless labor ... [but] never rise above their position.... They hate the rich.... They are densely ignorant, and easily aroused by prejudice or passion." The members of this class "are mainly Irish Catholics."

Not only words were invoked to control the dangerous classes. Of the 1,713 lynchings in the decade after 1882 (the first year for which accurate records exist), half of the victims were white (largely Jewish or Catholic); in the succeeding decade, a quarter were. 'Hunkies,' Italians, and Russian Jews could live and socialize only in a 'foreign colony' in an undesirable part of town. Unless there was a substantial black population in the area, most new immigrants occupied the lowest-skilled and lowestpaying jobs in the lowest-status industries. When able to attain jobs that required more expertise, they were paid less than their northern European counterparts.

Eventually, however, the despised races became the celebrated white ethnics. The reasons included genuine assimilation, the desire to become white in order not to be black, the almost complete cessation of new European immigration after World War I, upward mobility in a growing labor force, and political incorporation through party machines. By the 1960s, Irish Catholic families enjoyed on average $\$ 2,500$ more than the national average family income. ${ }^{5} \mathrm{An}$ Irish Catholic has been president of the nation, and during his presidential campaign John Kerry was coy about the fact that he is not Irish. Intermarriage rates among white ethnics are so high that demographers have largely given up trying to trace socioeconomic differences among nationalities. In short, the ethnic boundaries at the turn of the twentieth

\footnotetext{
5 Andrew Greeley, "Ethnic Minorities in the Unites States: Demographic Perspectives," International Journal of Group Tensions 7 (3 and 4) (1977): 64-97. See table 5-C for data.
} 
Jennifer L. Hochschild on race century that were sometimes etched in violence have mostly dissolved into shades of whiteness.

The transformation of the status of Asian immigrants has been even more phenomenal. In 1877, a U.S. Senate committee investigating Chinese immigration to California concluded that "the Chinese do not desire to become citizens of this country, and have no knowledge or appreciation for our institutions .... An indigestible mass in the community, distinct in language, pagan in religion, inferior in mental and moral qualities, and all peculiarities, is an undesirable element in a republic, but becomes especially so if political power is placed in its hands." Until the middle of the twentieth century, members of most Asian nationalities were prohibited from immigrating, becoming naturalized citizens, or owning certain types of property. Most Japanese Americans were interned in World War II, although few German Americans or Italian Americans were.

But now Asian Americans are perceived, often to their chagrin, as the 'model minority.' Elite private universities are rumored to use informal quotas to keep too many from beating out their non-Asian competitors. At the most prestigious state universities in California, where no such restrictions hold, Asian American students typically fill two-fifths of the student seats (in a state whose population is 12 percent Asian American). Almost half of adult Asian Americans have a college degree or more education, compared with three in ten Anglos, two in ten African Americans, and one in ten Latinos. A Newsweek cover story lauds the sex appeal of Asian men; analysts report that "Anglos living in close proximity to large Asian populations are more likely than racially and ethnically isolated Anglos to favor in- creased immigration." 6 As of 1990, a fifth of the children who had one Asian parent also had a parent of a different race; that proportion is surely much higher now. In the same year, 30 percent of Asians who married wed a non-Asian American, and that figure too is rising. While discrimination persists, virulently at times, and the label of 'foreigner' sometimes seems impossible to escape, it is not crazy to think that Asians may by 2050 have followed the path of Irish Catholics and Polish Jews into the status of 'just American.'

Conversely, another group of immigrants - Mexican Americans, or Latinos more generally - might become more sharply differentiated from other residents of the United States over the next few decades. Samuel Huntington argues that the "extent and nature of this immigration differ fundamentally from those of previous immigrations, and the assimilation successes of the past are unlikely to be duplicated with the contemporary flood of immigrants from Latin America. This reality poses a fundamental question: Will the United States remain a country with a single national language and a core Anglo-Protestant culture?"7 In this view, Latinos will follow the opposite trajectory from that of the Irish and Asians: Latinos, once perceived as part of an ethnicity with an identifiable but permeable culture, are becoming a race with increasingly defined boundaries.

The research evidence is completely mixed on this point. U.S.-born children

6 M. V. Hood III and Irwin Morris, “¿Amigo o Enemigo?: Context, Attitudes, and Anglo Public Opinion Toward Immigration," Social Science Quarterly 78 (2) (1997): 309-323.

7 Samuel P. Huntington, "The Hispanic Challenge," Foreign Policy (March/April 2004): $30-45$. 
of Mexican parents consistently receive more education than their parents,

speak English better, earn more at higher-status jobs, move away from gateway cities more frequently, marry more nonMexicans, and vote more. However, discrimination and subordination persist, and scholars such as Richard Alba and his coauthors find "no convincing sign of convergence in the educational attainments of later-generation Mexican Americans and Anglos." 8 That is, after the second generation, assimilation may lose its momentum. Sociologists even point to the possibility of a reversal, such that children and grandchildren of poor immigrants may lose ground economically, disengage politically, and end up with poorer health, higher rates of crime, or greater family instability than their ancestors or counterparts in their native country.

Huntington articulates a deeper anxiety: that the sheer magnitude of immigration and the high birth rates among Latinos who share a language, religion, and background and who mostly live in a distinct section of the United States are creating "a de facto split between a predominantly Spanish-speaking United States and an English-speaking United States." In my view, this concern is unwarranted; the culture of the United States is certainly changing in response to massive immigration from Latin America, but the immigrants are changing just as much, if not more. From the perspective of African Americans, in fact, the danger may be altogether too much assimilation rather than too little - creating once again a society in which

8 Richard Alba, Dalia Abdel-Hady, Tariqul Islam, and Karen Marotz, "Downward Assimilation and Mexican Americans: An Examination of Intergenerational Advance and Stagnation in Educational Attainment," University at Albany, SUNY, Albany, N.Y., 2004. immigrants get to become American by stepping over the only group that cannot, and does not want to, attain whiteness (or at least nonblackness).

Beyond the empirical complexities, I cannot forecast whether today's racial and ethnic categories will no longer be in use with regard to immigrants in 2050 , because of a crucial but unpredictable feature of immigration: the level and composition of immigration is largely a matter of political choice. U.S. immigration has not been drastically curtailed after forty years of increase, as it was in 1924 after about fifty years of a proportionally similar increase. But will it be? On the one hand, there are few signs of an impending cutoff. So the long period of incorporation with few newcomers that the United States experienced from 1920 until 1965 is unlikely to be repeated in the near future.

On the other hand, the war against terrorism may yet dramatically affect immigration laws and the treatment of immigrants. So far only a small segment of the population has been significantly affected. But arguably precedents have been set that could have powerful and, in my view, terrible consequences for the United States's treatment of 'foreigners.' And with a few more terrorist attacks, residents of the United States could develop a powerful nativism tinged with religious and ethnic hostility and fueled by a genuine and warranted fear. The effect such developments would have on the racial and ethnic categories of 2050 is anyone's guess. For most of the twentiech century, the boundary between black and white was as firmly fixed in law and self-definition as it was blurred in practice. This boundary did not always exist; in the 1600 , the Virginia legislature had to outlaw interracial marriages because too many 
Jennifer L. Hochschild on race white indentured servants were marrying black proto-slaves. Interracial sexual activity persisted, of course, and government policy in the centuries since then has shifted from counting mulattoes, quadroons, and octoroons to establishing "one drop of blood" laws in thirty states by 1940 . In some states or legal jurisdictions, not only blacks but also South Asians, Chinese and Japanese Americans, and Mexican Americans were forbidden to marry European Americans. Opponents used rumors of interracial sex to try to discredit Abraham Lincoln, the Populist movement, labor unions, New Deal agencies, desegregation in the Army, and the civil rights movement. The Supreme Court refused to take on cases of interracial marriage in the 1950 s for fear of evoking uncontrollable anger; Justice Harlan is reported to have said, with Thurgood Marshall's concurrence, that "one bombshell at a time is enough."

Most of that sentiment has disappeared, or at least gone underground. Multiracial identity is now a point of public pride and private assertion; a social movement built around multiracial identity has shown surprising strength. In 1958, only 4 percent of whites endorsed interracial marriage; the most recent Gallup poll shows that 70 percent now do. A recent cover of Parade magazine is adorned with smiling, adorable children under the headline of "The Changing Faces of America"; Mattel has introduced Kayla, whom it describes as "Barbie's racially ambiguous playmate"; The New York Times showcases "Generation E.A.: Ethnically Ambiguous"; Newsweek shows yet another set of adorable children in a story on "The New Face of Race." Whatever motives one attributes to the marketing of racial complexity, the fact that multiracialism now has commercial appeal shows how far it has moved from connotations of mongrelization and degeneration.

How much actual multiracialism there is in the United States is indeterminate. The answer depends on what one defines as a race (is a marriage between a Mexican American and a European American interracial?), whether interethnic marriages are factored in (how about a marriage between a Korean and a Japanese?), how far back one goes in a person's ancestry to determine multiraciality, and what individuals know or acknowledge in their own family history. Nevertheless, it is probably safe to say that intermarriage is rising, along with the number of children who are, or who are recognized as being, multiracial. Up to 12 percent of youth can now readily be called multiracial, and plausibly by 2050 about 10 percent of whites and blacks and over 50 percent of Latinos, Asians, and American Indians will marry outside their group.

Since families are comprised of more than only parents and children, a single intermarriage can have a wide impact. As of 1990, "one in seven whites, one in three blacks, four in five Asians, and more than 19 in 20 American Indians are closely related to someone of a different racial group. Despite an intermarriage rate of about 1 percent, about 20 percent of Americans count someone from a different racial group among their kin."9 And those calculations include neither marriages between or offspring of a Latino and a non-Latino, nor individuals with multiracial ancestry who consider themselves to be members of one racial group.

These changes in sentiment and behavior may grow even stronger over the

9 Joshua R. Goldstein, “Kinship Networks that Cross Racial Lines: The Exception or the Rule?" Demography 36 (3) (August 1999): 399 407. 
next few decades, as Latinos' celebration of mestizaje, the mixing of races, as a cultural identity and social environment, rather than as a description of an individual's ancestry, spreads across the nation. Similarly, the census's invitation to identify with more than one race may spread, for simple bureaucratic and nonideological reasons, to schools, state governments, corporations, hospitals, the criminal justice system, the military, and other far-reaching institutions. A frequently repeated offer to "check one or more" may encourage people to think of themselves as 'more than one.' If the trajectory of multiracialism persists, $\mathrm{Mi}$ gration News's speculation that today's racial and ethnic categories will no longer be in use in a few decades seems even less farfetched.

$\mathrm{W}_{\mathrm{e}}$ the fluctuating status of various immigrant groups, and the evolving connotation of multiracialism without considering African Americans. They are the perennial losers in the hierarchies of status, wealth, and power in the United States. The boundaries around blackness have been the most stringently monitored, first by oppressors and now perhaps by African Americans themselves; their relations with white Americans have been and continue to be the most fraught. If we knew how much the meaning of being black in the United States will change by 2050 - or more contentiously, whether racial oppression will be significantly undermined - we would know how seriously to take the speculation that our current racial and ethnic categories may become outmoded.

The standing of African Americans has changed dramatically over the past century: Republican President Roosevelt was widely criticized for once entertaining Booker T. Washington in the White House; Republican President Bush has entrusted two of the most important cabinet-level positions to African Americans. The highest paid corporate executive on Wall Street in 2003 was black; some African Americans hold high elective office or judgeships; some are esteemed socially and culturally. Overall, using criteria that encompass roughly half of the white population, about a third of American blacks can be described as middle class. Affluent African Americans can now pass their status on to their children, so a fully developed class structure has emerged in the black community.

Still, perhaps a third of African Americans remain at the bottom of the various hierarchies in the United States. Compared with all other groups, poor blacks are more deeply poor, for longer periods of their life and from earlier in childhood; they are more likely to live among other poor people. Black children who begin their education with roughly the same knowledge and skills as white children lose ground in the public school system. Blacks are more likely to be victimized by crime than any other group, and black men are much more likely to be incarcerated and subsequently disfranchised for life than are white men.

More generally, we cannot dismiss the possible persistence of what Orlando Patterson once called the "homeostatic principle of the entire system of racial domination," in which racial subordination is repressed in one location only to burst forth in another. ${ }^{10}$ Regardless of their income, African Americans are overcharged for used cars, less likely

10 Orlando Patterson, "Toward a Study of Black America,” Dissent (Fall 1989): 476- 486. 
Jennifer L. Hochschild on race to receive appropriate treatment for heart attacks, and less likely to receive excellent service from realtors and bankers. Blacks have drastically less wealth than whites with the same earnings. Whites seldom vote for black candidates when they have an alternative, and even less often move into substantially black neighborhoods, schools, and churches.

I am not sure what would count as persuasive evidence that the racial hierarchy in the United States is on a certain path to extinction. Certainly a strong black class structure that persists across generations would be essential (although it may merely substitute one hierarchy for another). A sense among African Americans that they can let down their guard - that embracing multiracialism is not just a way of inching closer to whiteness, that racism is only infrequently part of the explanation for a failure, that a commitment to racial solidarity need not take precedence over values such as feminism or patriotism or simple idiosyncrasy - would also be good evidence. And changed behavior by nonblacks, such as choosing a home or a child's school because of its quality rather than its racial composition, or repudiating implicit as well as explicit racial appeals by political candidates, or recognizing and disavowing the privileges that come with being the apparently raceless norm in U.S. society, would also be necessary.

Until we can be clear on what it will take to abolish racial hierarchy in the United States, and on how far we have moved toward that abolition, we cannot say whether by 2050 today's racial and ethnic categories will no longer be in use. If racial hierarchy persists, so will the categories of black and nonblack. Multiracialism and the history of American racial politics over the past few de- cades are on balance encouraging, but they are not dispositive. I turn finally to discrimination by skin tone, which may be the deepest and most tenacious form of racism in the United States. The connection between lightness and virtue is at least as old as Shakespeare, whose Timon of Athens learned too late that enough gold "will make black white, foul fair, wrong right, base noble, old young, coward valiant."

Europeans have not always denigrated dark-skinned people in favor of lightskinned ones, as Werner Sollors shows in An Anthology of Interracial Literature, but by the mid-nineteenth century, few residents of the United States publicly contested the view that lighter was better. Skin-color hierarchy held a fortiori across what we now call races; northern European whites were dominant, southern Europeans and Latinos held intermediate positions, and blacks were subordinated to all. But skin-color hierarchy also obtained within racial and ethnic groups, as phrases like 'the black Irish' and 'the brown paper bag test' and the advertising jingle asserting that 'blonds have more fun' attest.

The history of each racial or ethnic group includes its own variant of skincolor ranking. Spanish and Portuguese colonizers of Latin America elaborated rules for ranking according to a complex mixture of race, physical appearance, wealth, cultural heritage, and enslavement:

Whites generally have a superior status. People of Indian racial background whose cultural practices are mainly of Portuguese or Spanish derivation ... would be next on the social ladder. Mestizos, people of mixed indigenous and white background, would have a higher rating than those of largely Indian background. At the 
bottom of the social pyramid would be Afro-Americans, with mulattos occupying a higher social status than blacks. ${ }^{11}$

My research (conducted with Traci Burch and Vesla Weaver) suggests that skin-color ranking has had an equally powerful impact on African Americans. Compared with their darker-skinned counterparts, lighter-skinned black soldiers in the Civil War's Union Army were more likely to have been skilled workers than field hands before they entered the service. Sergeants and lieutenants were most likely to be lightskinned, and black soldiers with light skin were more likely than their darkerskinned counterparts to be promoted while in the Army. They were significantly taller (a measure of nutrition) and - most striking of all - the lightest members of the black regiments were significantly less likely to die in service. $^{12}$

Asian societies are not immune from the bias of skin-color ranking. An ancient Japanese proverb holds that "white skin makes up for seven defects," and Indian newspapers and websites carry personal ads for women whose parents boast of their daughters' purity and light skin in order to attract a husband. European Americans hold light skin in the same regard, as elucidated by that noted sociologist F. Scott Fitzgerald in This Side of Paradise. During a conversation about the virtues of strenuous exercise, Fitzgerald's Byrne suddenly observes,

11 Robert J. Cottrol, “The Long Lingering Shadow: Law, Liberalism, and Cultures of Racial Hierarchy and Identity in the Americas," Tulane Law Review 76 (November 2001): $11-79$.

12 These data are drawn from Jacob Metzer and Robert A. Margo, Union Army Recruits in Black Regiments in the United States, $1862-1865$, computer file, University of Michigan, Interuniversity Consortium for Political and Social Research, Ann Arbor, Mich., 1990.

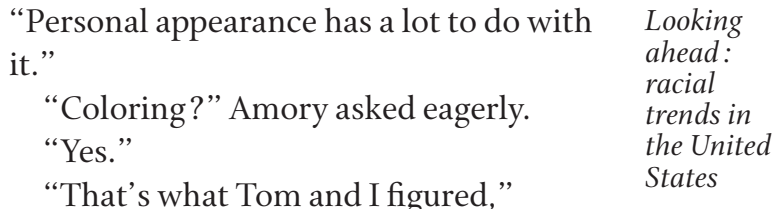

Amory agreed. "We took the year-books for the last ten years and looked at the pictures of the senior council .... It does represent success here [at Princeton University] in a general way. Well, I suppose only about thirty-five per cent of every class here are blonds, are really light - yet twothirds of every senior council are light...."

"It's true," Byrne agreed. "The lighthaired man is a higher type, generally speaking. I worked the thing out with the Presidents of the United States once, and found that way over half of them were light-haired, yet think of the preponderant number of brunettes in the race."

They go on for several more paragraphs in the same vein, apropos of nothing in the book's plot.

Such examples range across several centuries because the importance of skin tone has changed relatively little, despite the growth of a black cultural aesthetic, the Latino celebration of mestizaje, and the Asian drive for panethnic unity. Surveys from the 1990s show that lighterskinned African Americans and Hispanics continue to enjoy higher incomes and more education than their darker counterparts. They are more likely to own homes and to live among white neighbors, and less likely to be on welfare. Darker blacks and Latinos have higher rates of incarceration and unemployment; dark-skinned Mexican Americans speak less English and are less likely to be unionized if they are workers. Darkskinned black men convicted of a crime receive longer sentences than lighterskinned counterparts. Both blacks and whites attach more negative and fewer positive attributes to images of darkskinned, compared with light-skinned, blacks. 
Jennifer L. Hochschild on race
Controls for class background reduce but do not eliminate these differences. That is, light-skinned people are more likely to come from a well-off family reflecting the historical advantages of light skin - and they are more likely to be treated well by police, employers, teachers, and other citizens. The magnitude of these effects is impressive. One study found complexion to be more closely connected than was parents' socioeconomic status to blacks' occupation and income; another found that "dark-skinned blacks suffer much the same disadvantage relative to lightskinned blacks that blacks, in general, suffer relative to whites." 13 Even if racial and ethnic categories change drastically by 2050 , one cannot assume that skincolor hierarchy will do the same.

$\mathrm{O}$ ver the past century, the meaning of race and ethnicity has changed a lot, as have the status of most immigrants and the connotations of multiracialism. Skin-color hierarchy has changed little, and the subordination of African Americans has been challenged but not yet overthrown. Combining these dynamics in various ways and with varying degrees of emphasis permits us to envision at least six possible futures:

- The United States might persist in a structure of black exceptionalism, or an updated Jim Crow. In this scenario, skin tone and ethnicity would matter, but the main divide would continue to be between those identified as black and all others. That is, race as we now

13 Michael Hughes and Bradley R. Hertel, "The Significance of Color Remains: A Study of Life Chances, Mate Selection, and Ethnic Consciousness Among Black Americans," Social Forces 68 (4) (1990): 1105-1120; Verna Keith and Cedric Herring, "Skin Tone and Stratification in the Black Community," American Journal of Sociology 97 (3): $760-778$. understand it would trump skin tone and ethnicity among blacks, even if skin tone or ethnicity complicates the meaning of race for all other residents of the United States. Biracial individuals would be treated as simply black or nonblack, and would mostly identify according to that binary, rather than become a liminal or new category.

- A similar possible scenario is white exceptionalism. Here too, skin tone and ethnicity would continue to matter, but the main divide would be between those identified as white and all others. Skin tone and ethnic identification would continue to matter little among European Americans, who would all share to a greater or lesser degree in white privilege. Appearance and ethnic groupings might matter a great deal for sorting the rest of the population, but only within a shared subordinate status.

- Alternatively, the United States might move toward a South African model. That would combine the first two scenarios, producing a nation sorted into three groups: whites and 'honorary whites' (most Asians, some Latinos, and some biracials), coloreds (some Asians, most Latinos, some biracials, and a few African Americans), and blacks and almost-blacks (indigenous Latinos, many Native Americans, and some biracials, as well as African Americans). Levels of affluence, status, power, and vulnerability to discrimination would on average vary accordingly, with wider variations between rather than within the groups. ${ }^{14}$

14 For more on this scenario, see Eduardo Bonilla-Silva, "We Are All Americans!: The Latin Americanization of Race Relations in the United States," in Maria Krysan and Amanda Lewis, eds., The Changing Terrain of Race and 
- Perhaps the United States will sort along a more complex set of racial and ethnic dimensions, with new understandings of race and ethnicity. One possibility is sharper regional divides. Thus the Northwest would mingle Asians, Native Americans, and Anglos; the Southwest would mix Latinos, Native Americans, and Anglos; the Midwest would remain largely Anglo; the South would continue to hold mostly separate populations of blacks and Anglos, and so on. These regional divides could develop important political and cultural implications, even if not at the level of the antebellum North, South, and West as described by Anne Norton, among others. ${ }^{15}$ Or the nation might divide along lines of nativity, so that the most salient characteristic is whether one is foreign- or native-born. Perhaps class lines or intensity of religious commitment or isolationism would cut across lines of race, ethnicity, and skin tone alike.

- The United States might be moving toward the eventual elimination of distinct racial and ethnic groups in favor of a skin-color hierarchy, tout court. Socioeconomic status, prestige, and political power would in that case depend on one's location on that continuum; identity, beliefs, and perceptions would eventually follow. Whether such a continuum would improve the United States's racial order by substituting fluidity for rigidity, or worsen it by disguising persistent racial stigma through a series of small gradations, remains to be seen.

Ethnicity (New York: Russell Sage Foundation, 2004): 149-183.

15 Anne Norton, Alternative Americas: A Reading of Antebellum Political Culture (Chicago, Ill. : University of Chicago Press, 1986).
- Finally, the United States might blur distinct racial and ethnic groups into a multiracial mélange. The logic of multiracialism differs from that of skin color since the former is not inherently Looking ahead: racial trends in the United States

hierarchical: black/white individuals have the same standing qua 'multiracials' as do Asian/Latino individuals. The crucial divide in this scenario would be between those who identify as monoracials and seek to protect cultural purity and those who identify as multiracials and celebrate cultural mixing. Skin tone, along with conventional distinctions of race and ethnicity, would recede in importance.

Prediction is a fool's game. The future will be partly controlled by political and policy choices not yet made, perhaps not yet even imagined. Furthermore, as others discuss in detail in this issue of Doedalus, the very categories that we employ to measure racial and ethnic change will themselves affect the direction and magnitude of that change. The census is not a neutral bean counter; Heisenberg's principle holds for the social as well as the physical world. Nevertheless, I will venture a guess: skin tone will continue to be associated with invidious distinctions; African Americans will remain a distinct although not always subordinated social grouping; and everything else in this arena - our understandings of race and ethnicity, our treatment of immigrants, our evaluation of people and cultures that cut across formerly distinct categories - is up for grabs. 